\title{
The morphofunctional design of Montealtosuchus arrudacamposi (Crocodyliformes, Upper Cretaceous) of the Bauru Basin, Brazil
}

\author{
Sandra Aparecida Simionato Tavares ${ }^{\mathrm{a}, \mathrm{b}}$, Fresia Ricardi Branco ${ }^{\mathrm{a}}$, \\ Ismar de Souza Carvalho ${ }^{c, *}$, Lara Maldanis ${ }^{\mathrm{d}, \mathrm{e}}$ \\ a Universidade Estadual de Campinas (UNICAMP), Instituto de Geociências, Cidade Universitária, Rua João Pandiá Calógeras, 51, 13083-870, Campinas, SP, \\ Brazil \\ b Museu de Paleontologia "Prof. Antonio Celso de Arruda Campos", Praça do Centenário-s/n - Centro, Monte Alto, SP, Brazil \\ c Universidade Federal do Rio de Janeiro, Centro de Ciências Matemáticas e da Natureza, Instituto de Geociencias, Departamento de Geologia, Cidade \\ Universitária, Ilha do Fundão, Av. Athos da Silveira Ramos, 274, Bloco G, 21941-916 Rio de Janeiro, RJ, Brazil \\ d Universidade de São Paulo, Instituto de Física de São Carlos, Av. Trabalhador são-carlense, 400, Pq. Arnold Schimidt, 13566-590, São Carlos, SP, Brazil \\ e Laboratório Nacional de Luz Síncrotron, Centro Nacional de Pesquisas em Energia e Materiais, Rua Giuseppe Máximo Scolfaro, 10.000 - Polo II de Alta \\ Tecnologia de Campinas, 13083-970, Campinas, SP, Brazil
}

\section{A R T I C L E I N F O}

\section{Article history:}

Received 19 April 2017

Received in revised form

22 June 2017

Accepted in revised form 9 July 2017

Available online 11 July 2017

\section{Keywords:}

Biomechanics

Crocodyliformes

Montealtosuchus arrudacamposi

Bauru Basin

\begin{abstract}
A B S T R A C T
Montealtosuchus arrudacamposi, a Peirosauridae from the Upper Cretaceous of the Bauru Basin, was a Crocodyliformes of terrestrial habits. The fossils analyzed in this study belong to the pectoral girdle (scapula and coracoid) and anterior appendicular skeleton (humerus, radius, ulna, carpals, radiale, ulnale, metacarpals and phalanges). In this study we infer the locomotion habits of M. arrudacamposi. A morphometric, morphofunctional and 3D reconstruction of the elements of the pectoral girdle and the anterior limbs of $M$. arrudacamposi were performed. For a better understanding of the most plausible pectoral girdle and anterior limb posture, the studied bones were virtually disarticulated and articulated on $3 \mathrm{D}$ reconstruction.

The herein results obtained indicate the structures present a relatively thin and elongated aspect, thus allowing an interpretation that $M$. arrudacamposi possessed more slender anterior limbs than living crocodyliforms. This condition allowed for an adducted stance and cursorial habits that would enable movement through terrestrial environments for prey searching.
\end{abstract}

๑) 2017 Elsevier Ltd. All rights reserved.

\section{Introduction}

In order to understand the way of life of an extinct species is necessary to consider all the evidences preserved in a bone structure, and thus understanding its functionality. Benton (2010) states that there are several ways to research the behavior of a species through fossils. One of them is to evaluate the bones' joints and make inferences regarding the shape of the extremities on preserved structures.

Selden (1990) also argues that through the morphology of the bony structures of vertebrates, and the features preserved in them, it is possible to test hypotheses about their functionality. Several

\footnotetext{
* Corresponding author.

E-mail addresses: sandraastavares@uol.com.br (S.A.S. Tavares), fresia@ige. unicamp.br (F.R. Branco), ismar@geologia.ufrj.br (I.S. Carvalho), laramcp@hotmail. com (L. Maldanis)
}

authors (Bakker, 1971; Charig, 1972; Bonaparte, 1986; Sennikov 1987; Kischlat, 2000) have based their work on, among other aspects, the graduation in angles to determine the abduction of the femoral axis and understand the posture and locomotion of tetrapods. However, information contained in the bones of the anterior limbs, such as the humerus, can also provide data regarding the posture of parts of a given species.

Fossil Crocodyliformes are well-represented in sedimentary deposits of Bauru Basin in the municipality of Monte Alto, State of São Paulo, Brazil. Among them, is the Peirosauridae Montealtosuchus arrudacamposi (Carvalho et al., 2007), that presents excellent preservation of the bony elements that compose its skeleton. It has the skull, mandible, postcranial elements and dermal shield preserved practically in their original positions (Fig. 1).

In this study, a morphological and morphofunctional description of the bones, constituting the pectoral girdle and anterior 


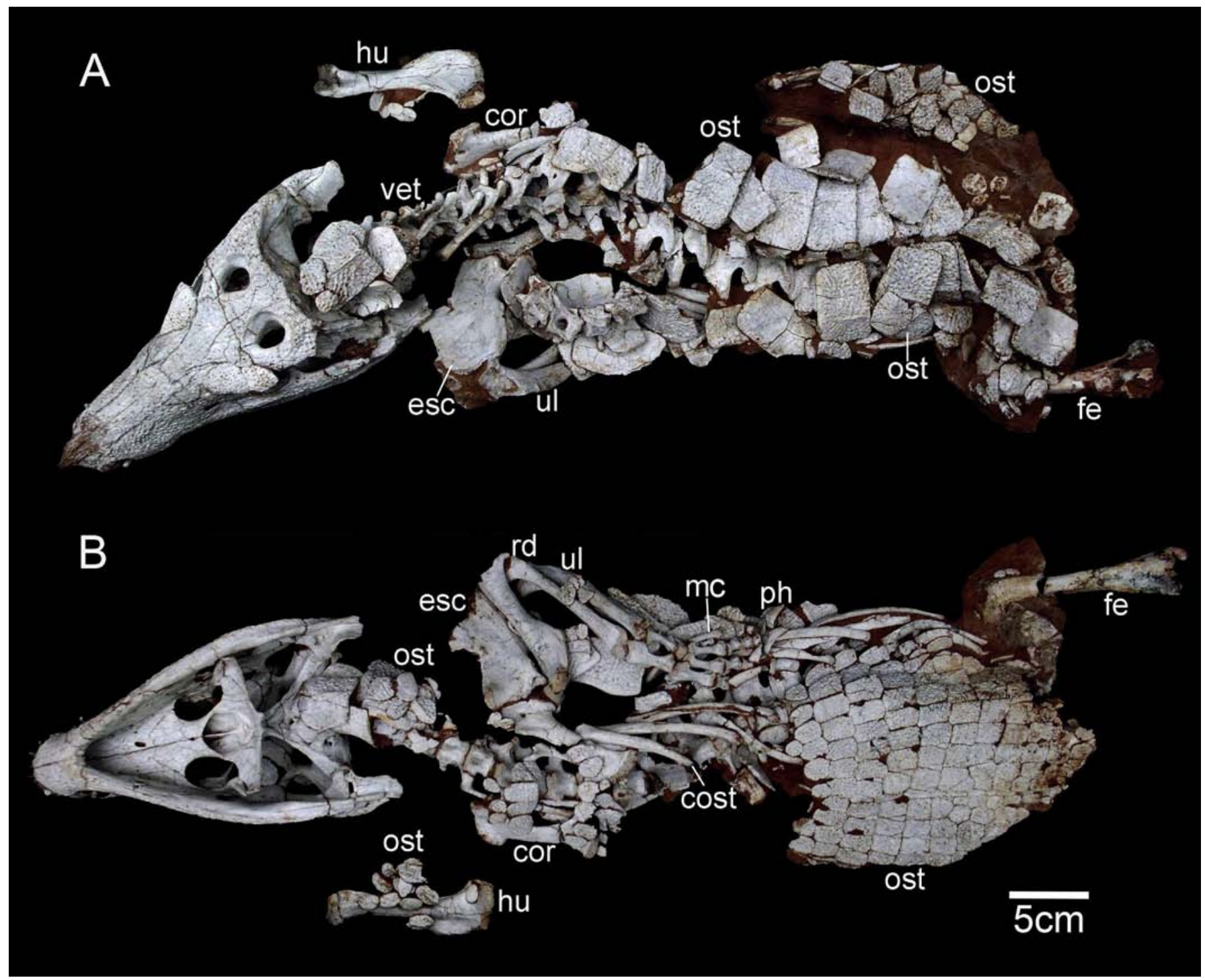

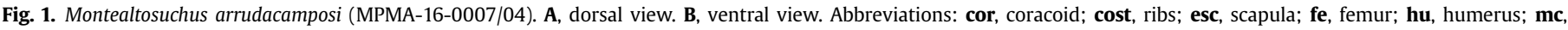
metacarpus; ost, osteoderms; ph, phalanges; rd, radius; ul, ulna; vet, vertebra.

appendicular elements of $M$. arrudacamposi, was performed to understand its locomotory habits.

\section{Geological context}

Bauru Basin is located in the south-central region of the South American Platform and is distributed in the states of São Paulo, Minas Gerais, Mato Grosso do Sul, Goiás and northeastern Paraguay, adding up to an area of approximately $370,000 \mathrm{~km}^{2}$ between latitudes $18^{\circ} \mathrm{S}$ and $24^{\circ} \mathrm{S}$, and longitude $47^{\circ} \mathrm{W}$ and $56^{\circ} \mathrm{W}$ (Fernandes and Coimbra, 1996). According to Menegazzo et al. (2016) the Basin's development occurred from the Cenomanian to early Paleocene in the back-bulge province of a retroarc foreland system that came to existence in response to Andean orogenic events. It is divided into two lithostratigraphic units: the Caiuá Group (Paraná River, Goio Erê and Santo Anastácio formations) and the Bauru Group (Adamantina, Uberaba and Marília formations) (Fernandes, 1998; Dias-Brito et al., 2001).

The sedimentary fill formed by the Bauru Group corresponds to continental deposits. It is composed of fluvial sediments
(Adamantina and Uberaba Formations) and alluvium (Marília Formation) (Fernandes and Coimbra, 2000). In the region of Monte Alto there are two lithostratigraphic units of the Bauru Group surface: the Adamantina's and the Marilia's Formations.

The fossils of the Montealtosuchus arrudacamposi were found in rocks from the Turonian-Santonian (Upper Cretaceous) of the Bauru Basin, Bauru Group, Adamantina Formation in the region of Monte Alto (S $21^{\circ} 09^{\prime} 53.9^{\prime \prime} \mathrm{W} 48^{\circ} 29^{\prime} 54.0^{\prime \prime}$ ), São Paulo State, Brazil (Fig. 2). These specimens were preserved in a succession of thin to medium layers of loosely-cemented reddish sandstone. The strata overlaying this layer are composed of fine sandstone with remains of tetrapods and bivalves. Finally, there is a highly cemented conglomerate layer containing coprolites, as well as teeth and isolated bone elements from dinosaurs, chelonians, and squamata.

According to Carvalho and Bertini (2000), the paleoclimate during the deposition of the Adamantina Formation is characterized as warm with torrential rains and floods. Basilici et al. (2009) states, based on the study of paleosols, that the Marília Formation was characterized during the Late Cretaceous by a semi-arid climate. 


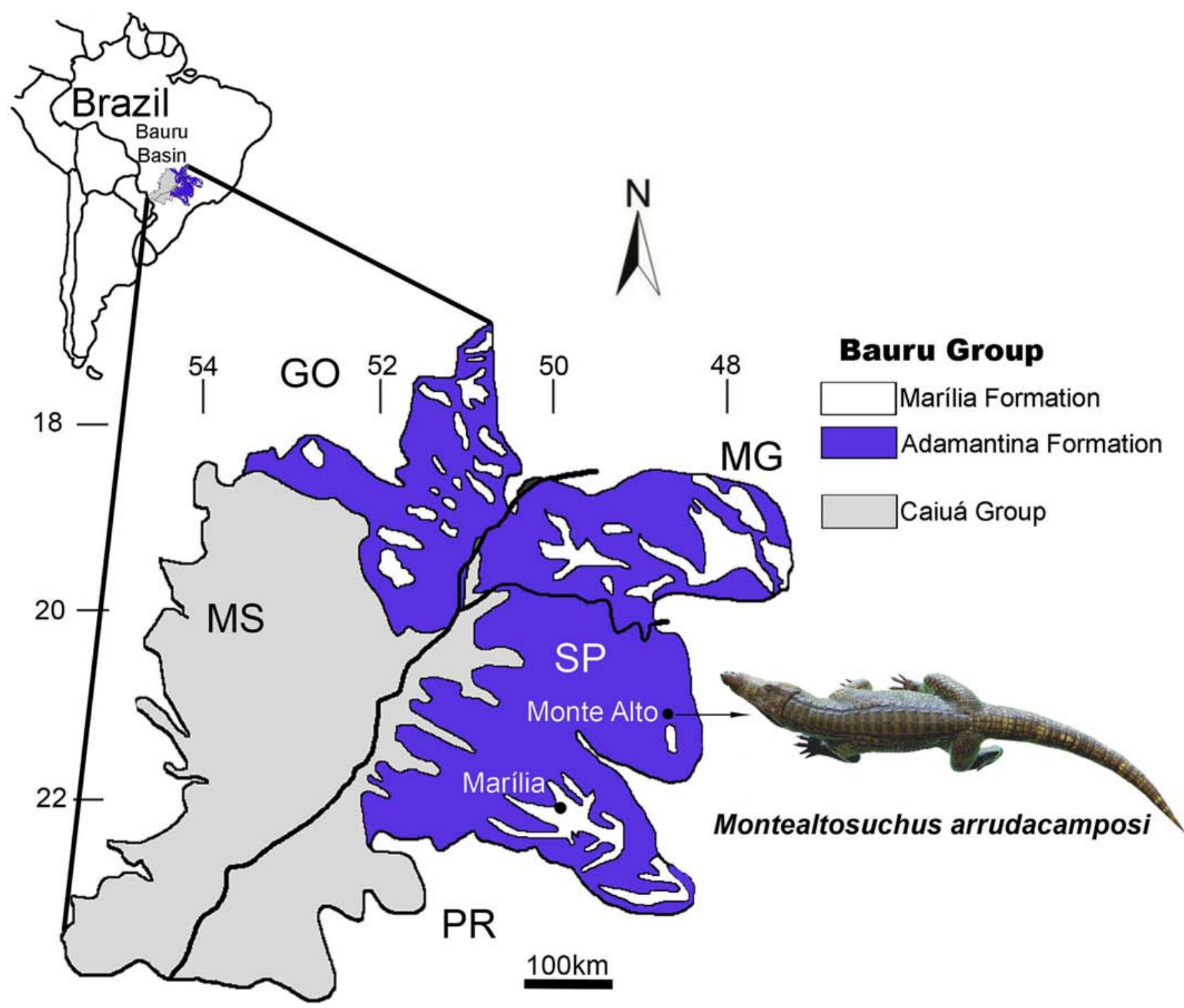

Fig. 2. Geological Map of the Bauru Basin. Go, Goiás; MG, Minas Gerais; MS, Mato Grosso do Sul; PR, Paraná; SP, São Paulo (modified from Fernandes and Coimbra, 1996).

According to Carvalho et al. (2010), an arid or a warm climate, dry seasonal climate with alternated wetter periods, could have influenced the wide diversity of crocodilians in Gondwana during the Cretaceous. According to Iori et al. (2016), in the Adamantina Formation of the Monte Alto region, the Morrinhosuchus and Caipirasuchus crocodyliform specimens are autochthonous and occur in typical paleosol deposits, whereas Barreirosuchus and Montealtosuchus are in deposits of fluvial and/or lacustrine environment.

The remains of $M$. arrudacamposi were found in association with fragments of another skull corresponding to the left side, and there are other several postcranial fragments of at least four other individuals that appear to belong to the same species (Tavares et al., 2015). According to Carvalho et al. (2005), the occurrence of almost complete articulated skeletons suggests these animals could dig large deep burrows in soft substrates that allowed thermoregulation, like in living alligators.

The number of cranial peirosaurid specimens, preserved along the $M$. arrudacamposi holotype, suggests these animals lived in groups and that they may have also had the habit of burying themselves in the substrates just like current crocodyliforms.

\section{Materials and methods}

\subsection{Post-cranial elements of M. arrudacamposi}

The fossil bones analyzed in this study were: coracoids - right and left - and left scapula (pectoral waist); humeri - left and right, and left radius, ulna, distal carpals, radiale, ulnare, metacarpals and phalanges (left appendicular skeleton) of the holotype of M. arrudacamposi (Fig. 3B). This specimen is housed in the Museum of Paleontology "Prof. Antonio Celso de Arruda Campos", based in the city of Monte Alto-SP, collection number MPMA-16-0007/04. The measures were taken with MAUb-CH Stainless steel calipers and a tape measure.

\subsection{Nomenclature and taxa compared}

The terms used for the anatomical nomenclature of osteology are the same as those used by Mook (1921), Romer (1956), Richardson et al. (2002) and Buckley and Brochu (1999), Hoffstetter and Gasc (1973), Tarsitano (1982). To assign postural and locomotory patterns, von Huene's (1913) proposal was used 
A

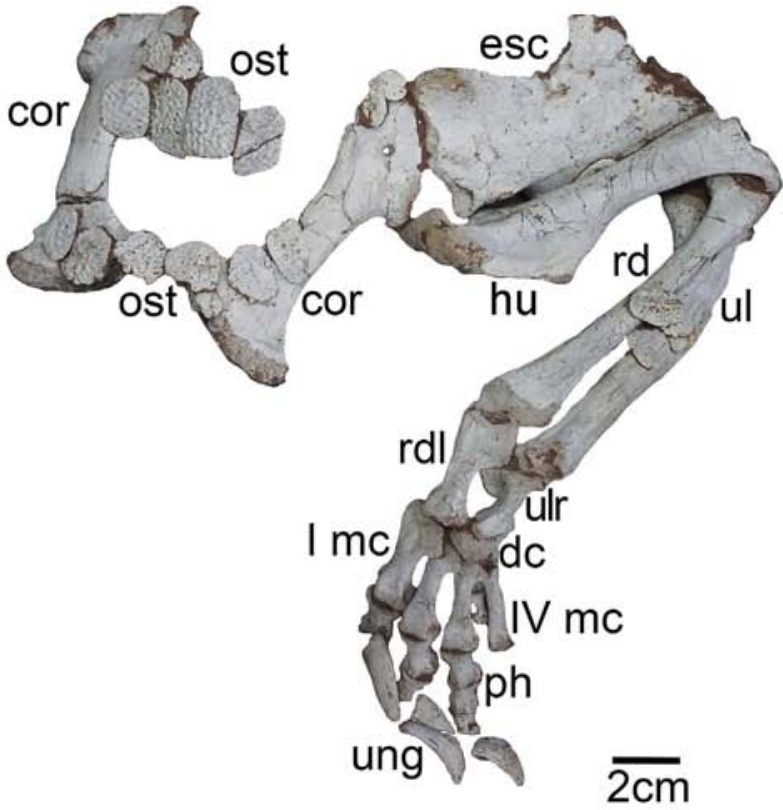

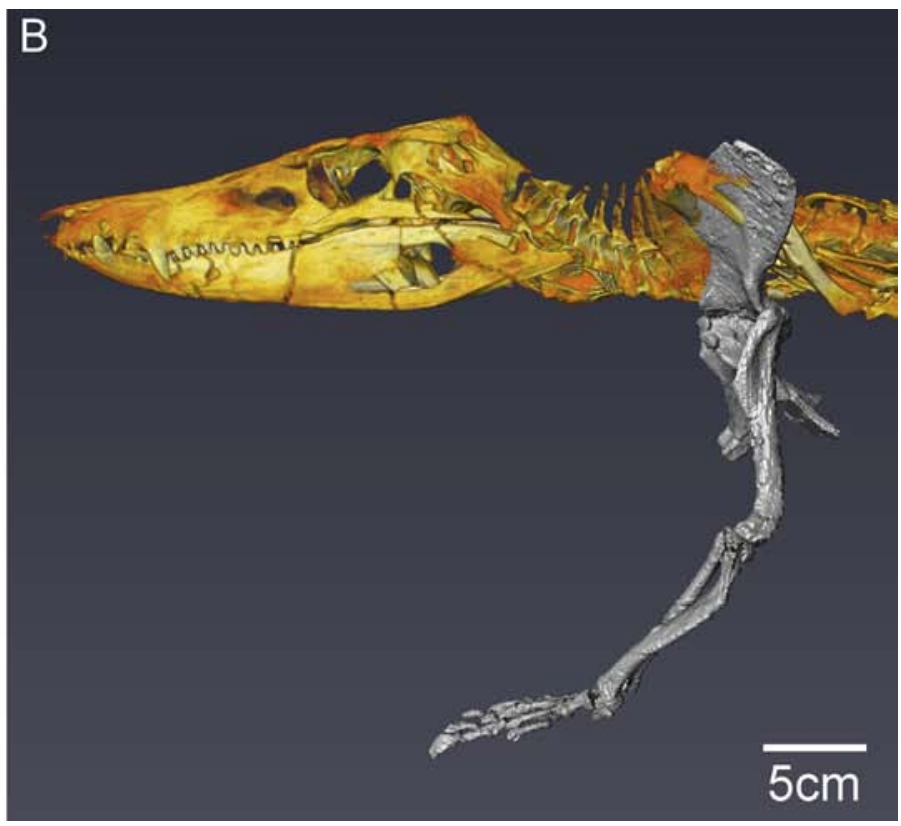

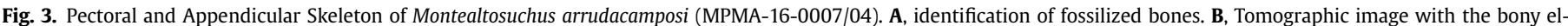

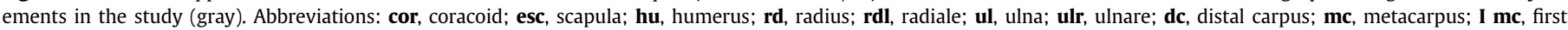
metacarpal; IVmc, fourth metacarpal; ost, pectoral osteoderms; ph, phalanges; ung, ungual phalanx.

and compared with data from living and fossil crocodyliforms (Table 1).

\subsection{Computed tomography and $3 D$ images}

The holotype of M. arrudacamposi was scanned at the Institute of Radiology, Faculty of Medicine, São Paulo USP, Brazil, using the Discovery CT750 HD CT Scanner, GE Health Systems, Milwaukee,

Table 1

Taxa used as references to analogies with Montealtosuchus arrudacamposi.

\begin{tabular}{|c|c|}
\hline Species & References \\
\hline Alligator mississipiensis Daudin, 1802 & Klein, 2016 \\
\hline $\begin{array}{l}\text { Junggarsuchus sloani Clark, Xu, Forster and } \\
\text { Wang, } 2004\end{array}$ & Clark et al., 2004 \\
\hline $\begin{array}{l}\text { Uberabasuchus terrificus Carvalho, Ribeiro } \\
\text { and Avilla, } 2004\end{array}$ & Vasconcellos, 2006 \\
\hline Araripesuchus tsangatsangana Turner, 2006 & Turner, 2006 \\
\hline $\begin{array}{l}\text { Stratiotosuchus maxhechti Campos, Suarez, Riff } \\
\text { and Kellner, } 2001\end{array}$ & Riff and Kellner, 2011 \\
\hline $\begin{array}{l}\text { Baurusuchus salgadoensis Carvalho, Campos } \\
\text { and Nobre, } 2005\end{array}$ & Vasconcellos et al., 2007 \\
\hline Baurusuchus albertoi Nascimento and Zaher, 2010 & $\begin{array}{l}\text { Nascimento and Zaher, } \\
2010\end{array}$ \\
\hline $\begin{array}{l}\text { Pissarrachampsa sera Montefeltro, Larsson } \\
\quad \text { and Langer, } 2011\end{array}$ & Godoy et al., 2016 \\
\hline $\begin{array}{l}\text { Campinasuchus dinizi Carvalho, Teixeira, Ferraz, } \\
\text { Ribeiro, Martinelli, Neto, Sertich, Cunha, } \\
\text { Cunha and Ferraz, } 2011\end{array}$ & Cotts et al., 2017 \\
\hline Mariliasuchus amarali Carvalho and Bertini, 1999 & $\begin{array}{l}\text { Nobre and Carvalho, } \\
2013\end{array}$ \\
\hline Notosuchus terrestris Woodward, 1896 & Pol, 2005 \\
\hline $\begin{array}{l}\text { Simosuchus clarki Buckley, Brochu, Krause and Pol, } \\
2000\end{array}$ & $\begin{array}{l}\text { Sertich and Groenke, } \\
2010\end{array}$ \\
\hline $\begin{array}{l}\text { Yacarerani boliviensis Novas, Pais, Pol, Carvalho, } \\
\text { Mones, } \\
\text { Scanferla and Riglos, } 2009\end{array}$ & Leardi et al., 2015 \\
\hline $\begin{array}{l}\text { Caipirasuchus montealtensis (Andrade and Bertini, } \\
\text { 2008) }\end{array}$ & Iori et al., 2016 \\
\hline $\begin{array}{l}\text { Armadillosuchus arrudai Marinho and } \\
\text { Carvalho, } 2009\end{array}$ & $\begin{array}{l}\text { Marinho and Carvalho, } \\
2009\end{array}$ \\
\hline
\end{tabular}

USA. The CT images were segmented in InVesalius 3.0 software, developed at the Three-Dimensional Technologies Division, (Renato Archer Information Technology Center, city of Campinas, São Paulo- Brazil), and at the Brazilian Synchrotron Light Laboratory (LNLS), CNPEM (Campinas, São Paulo - Brazil), using the Avizo 9.0 program of the FEI Visualization Sciences Group, software that allows separation of the fossilized structures of the matrix using the contrast generated by their difference in density.

After segmentation of the CT slices, 3D models of the structures were generated (Fig. 3), thus allowing a reorganization of the bones by placing them in the most correct position, according to the morphological information available in the fossils.

\section{Results}

\subsection{Scapula (Fig. 4)}

Only the left scapula, about $90 \mathrm{~mm}$ in length, is preserved in the holotype of $M$. arrudacamposi. It has an anteroposterior expansion giving rise to the scapular blade. This structure is very thin, approximately $1 \mathrm{~mm}$ thick. In the lateral view a more evident constriction is observed in the distal portion of the scapula. The posterior concavity is posteriorly positioned at the distal end.

In lateral view two crests are evident, one lateral anteriorly in the distal portion and the other lateral posteriorly originating from the proximal end, being more evident at the distal end. There is a well-defined concavity in the medial view's most distal portion. The glenoid cavity is concave and located ventrally in the distal portion of the scapula.

\subsection{Coracoids (Fig. 5)}

The right and left coracoids were preserved practically in their original position, connected in both, the proximal and distal portions by a set of osteoderms, which make up the pectoral dermal shield of M. arrudacamposi (Tavares et al., 2015). They are 
A

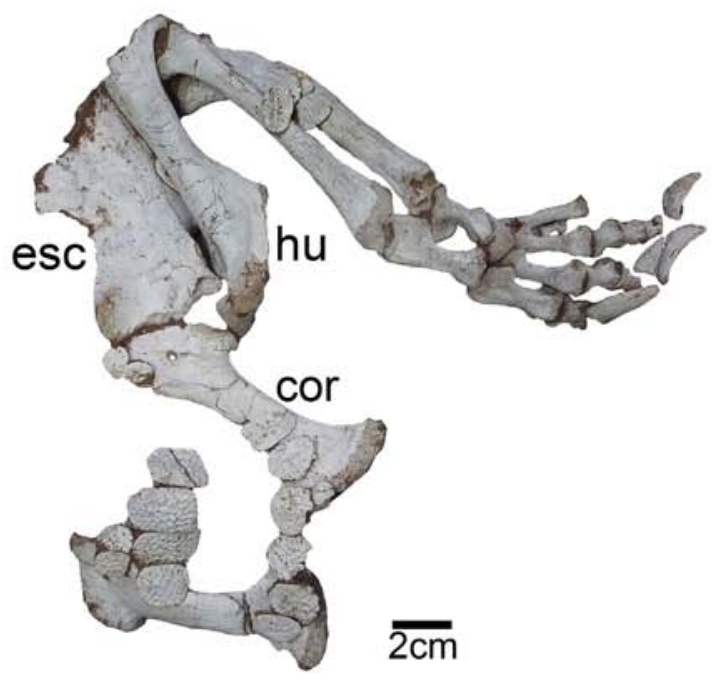

B

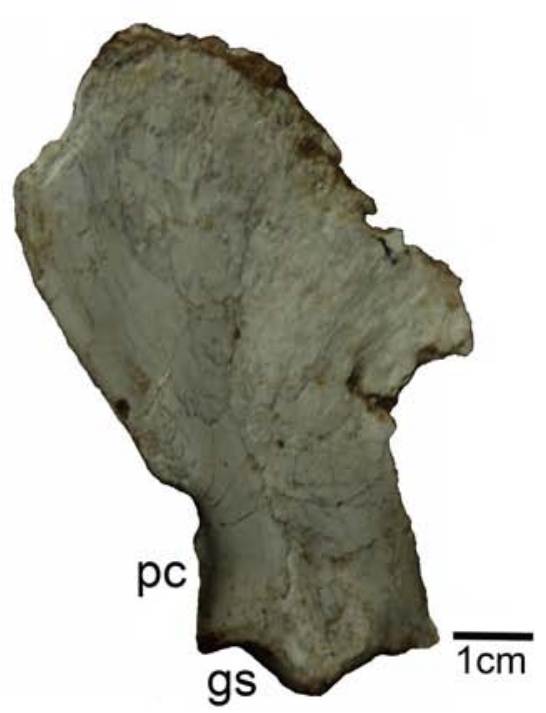

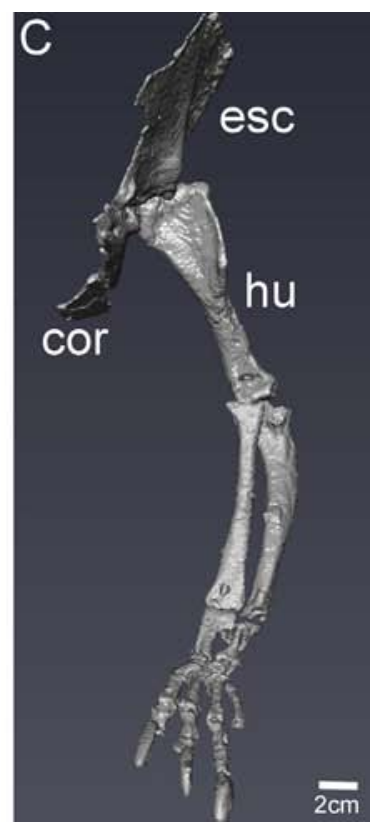

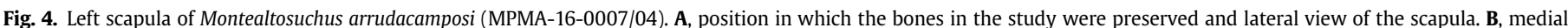

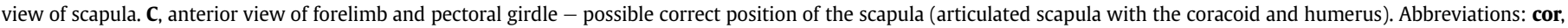
coracoid; gs, glenoid surface; esc, scapula; hu, humerus; pc, posterior concavity.

approximately $80 \mathrm{~mm}$ long and have a posterior concavity in the region of the diaphysis.

In both coracoids the coracoid foramen is preserved centrally at the proximal end. The contact surface with the scapula is relatively flat, and the glenoidal one is posteromedially oriented. The humeral joint surface is slightly concave. Medially, below the joint surface for the humerus, there is a well-defined groove (posterior sulcus). There is distal expansion of the coracoid.

\subsection{Humerus (Fig. 6)}

Both humeri of $M$. arrudacamposi are preserved. They are approximately $110 \mathrm{~mm}$ in length. The left humerus is damaged in the distal epiphysis and preserved coupled to the coracoid and scapula, but displaced from its original position. The right humerus is disarticulated from the coracoid and the scapula (Fig. 1).

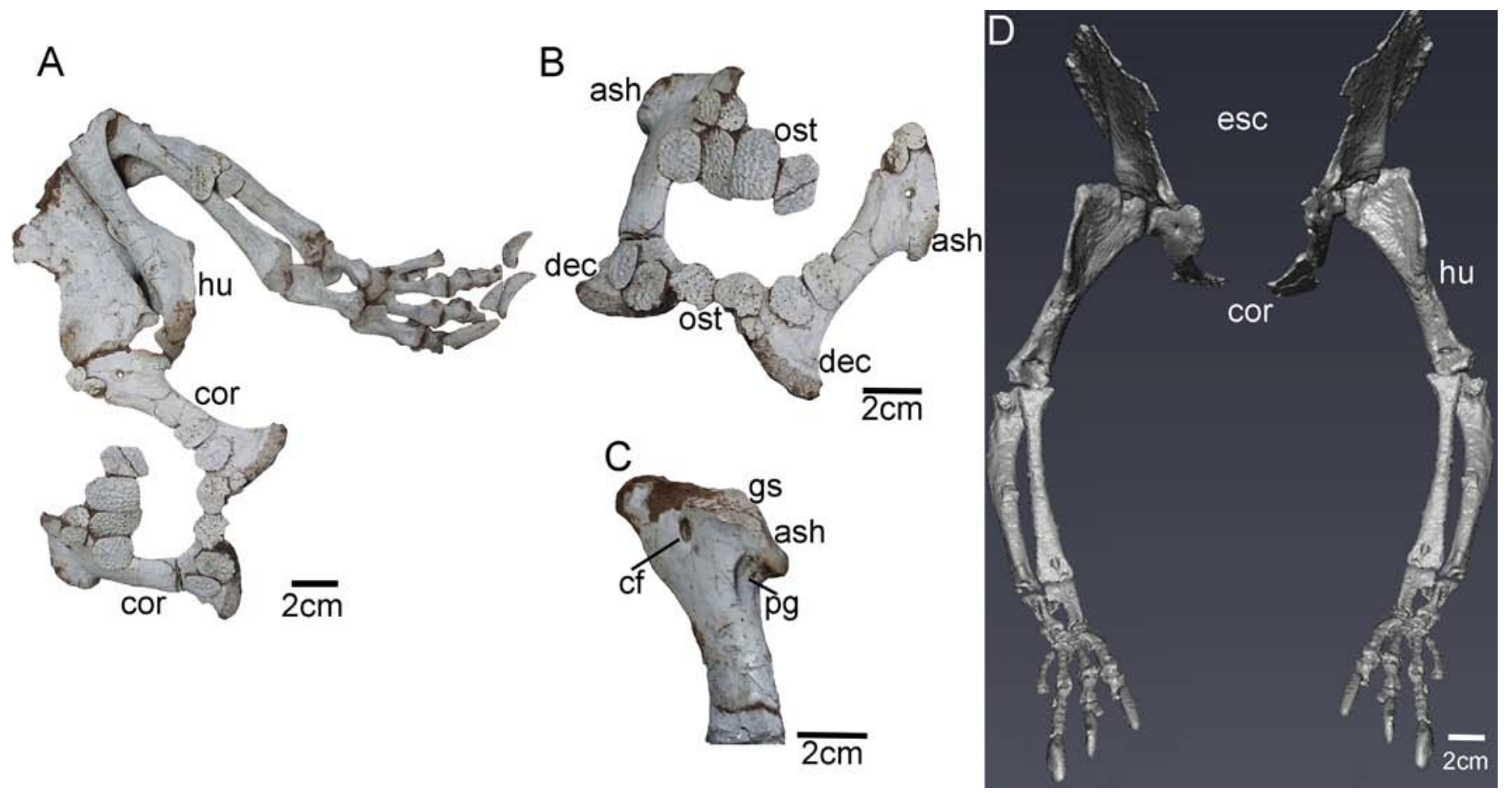

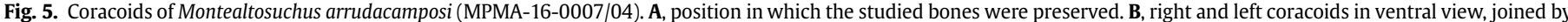

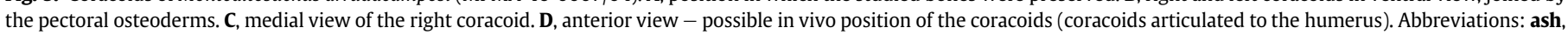

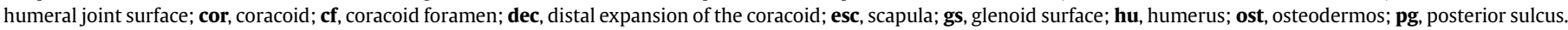



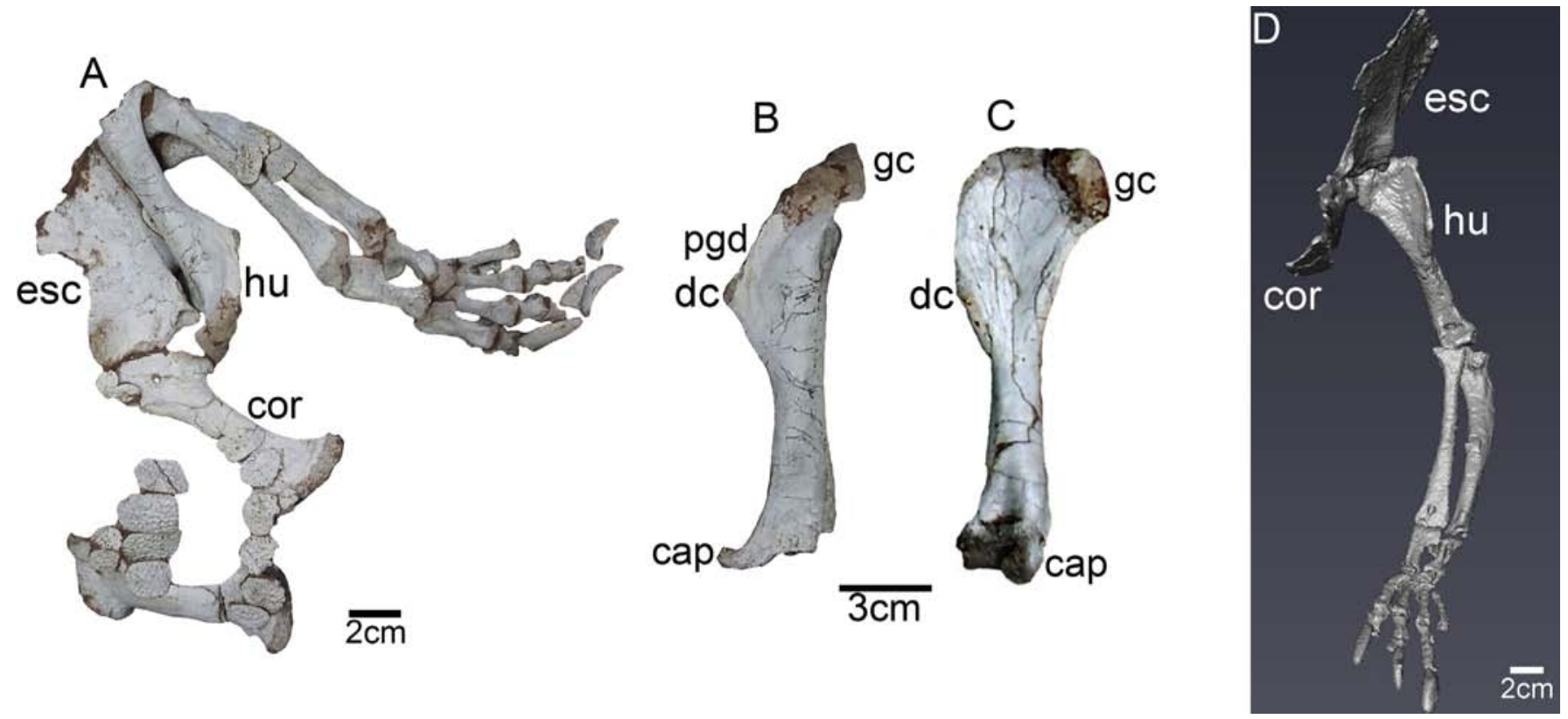

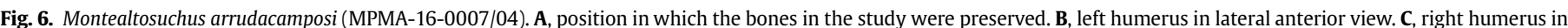

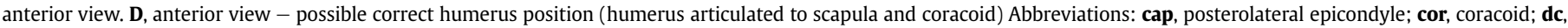
deltoid crest; esc, scapula; gc, glenohumeral condyle; hu, humerus; pdg, posterior deltoid sulcus.

In the lateral view, both the left and right humeri have a sigmoidal shape. The proximal end is expanded lateromedially and an attenuated concavity is seen the anterior view. The joint surface of the humeral head for the glenoid cavity is convex.

The deltopectoral crest develops dorsolaterally extending distally to the beginning of the diaphysis. In the posterior view a depression is visible at the proximal end.

The diaphysis of the humerus of M. arrudacamposi is cylindrical, approximately $40 \mathrm{~mm}$ long and $15 \mathrm{~mm}$ in diameter. The distal end is preserved in the right side humerus. There is a pronounced concavity anteriorly. The lateral and medial epicondyles are convex, anteriorly projected and separated by the concavity.

\subsection{Ulna (Fig. 7)}

The ulna of $M$. arrudacamposi is articulated to the radius. Only the left ulna of approximately $100 \mathrm{~mm}$ long is preserved. Laterally it has a distinct sigmoidal shape. The proximal end is
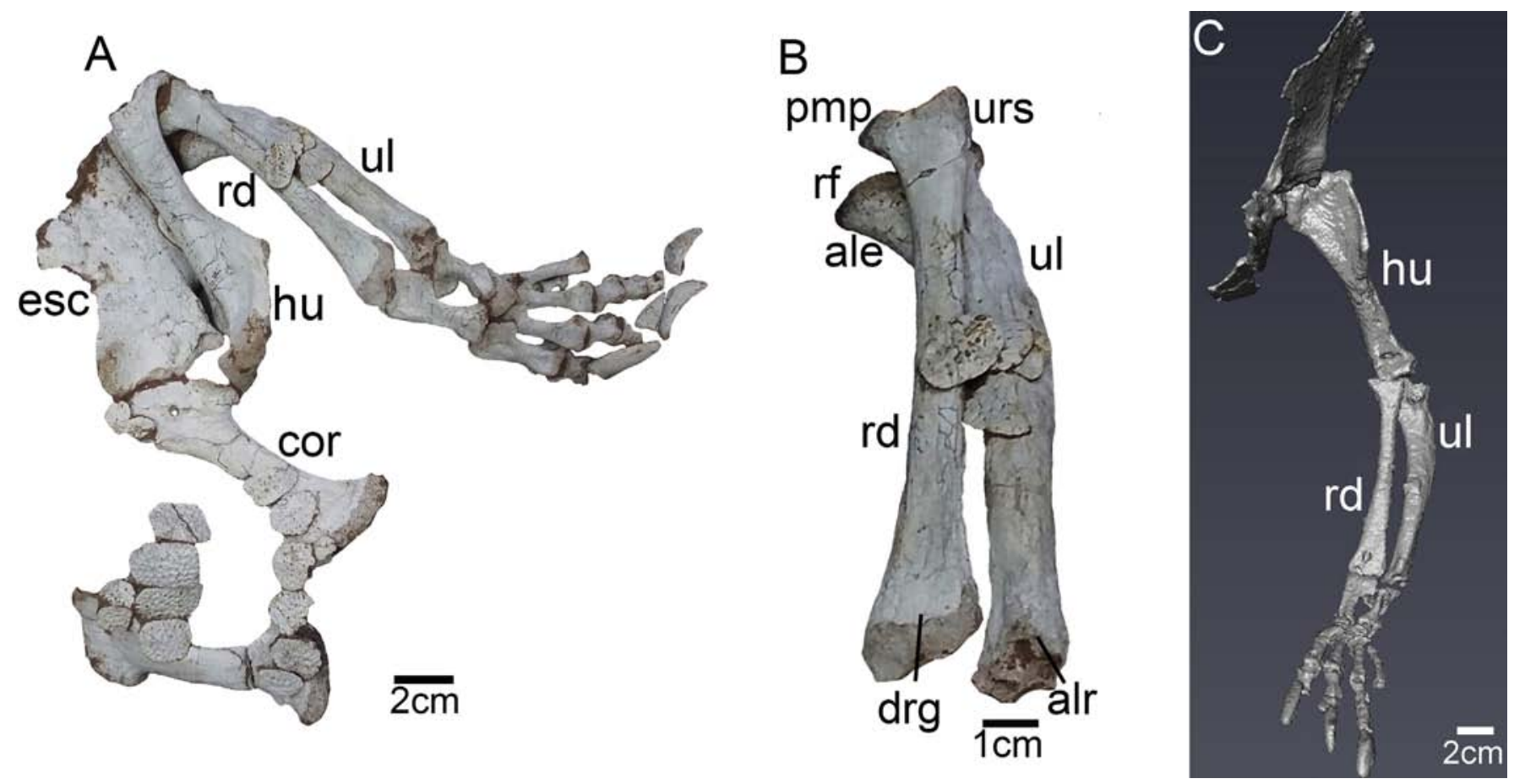

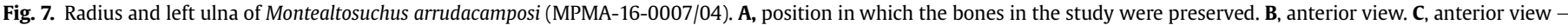

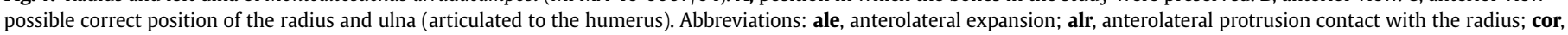
coracoid; esc, scapula; drg, radial distal sulcus; hu, humerus; pmp, posteromedial process; rd, radius; rf, radial facet; ul, ulna; urs, radiohumeral ulnar surface. 
elliptical in cross section. In the posterior view, the proximal end is damaged and the olecranon has not been preserved. The diaphysis measures $80 \mathrm{~mm}$ and two thirds of it, from the proximal epiphysis, are considerably flattened. In the remainder of its length the diaphysis becomes more cylindrical. The distal epiphysis is also damaged.

\subsection{Radius (Fig. 7)}

Only the left radius is preserved in this specimen. It has the same length as the ulna $(100 \mathrm{~mm})$. The epiphyses were not completely preserved; however, it is possible to observe an expansion medially at both, the proximal and distal ends.

The proximal half of the diaphysis is circular in cross-section. However, towards the distal end it becomes compressed. In the anterior view, an osteoderm of the appendicular shield (Tavares et al., 2015) is observed on the diaphysis.

\subsection{Anterior autopodium (Fig. 8)}

The bones that make up the front foot (radiale, ulnare, pisiform, carpals, metacarpals and phalanges) are well preserved and practically in life position.

\subsubsection{Radiale (Fig. 8)}

The radiale measures $30 \mathrm{~mm}$ and articulates with the distal epiphysis of the radius. The proximal radiale epiphysis is wellexpanded medially. The proximal and distal joint surfaces are concave, and the proximal surfaces have a somewhat more defined concavity than the distal one. Dorsomedially, at both the proximal and distal ends, there is a surface for the articulation of this bone at the distal end of the ulna and the ulnar condyles.

\subsubsection{Ulnare (Fig. 8)}

The ulnare is one-third smaller than the radiale. The articulation surface of the proximal epiphysis is flat and poorly developed. It articulates medially to the proximal epiphysis of the radiale and laterally to the distal epiphysis of the ulna. The distal epiphysis is well-expanded laterally and medially. In the dorsal view, it is in contact with the medial distal portion of the radial epiphysis. Ventrally articulates with the dorsal region of the distal carpus and proximal portion of the pisiform.

\subsubsection{Pisiform (Fig. 8)}

The pisiform is a bone that articulates proximally to the ulna and medially to the ulnare. It is expanded lateromedially in the distal portion, forming a surface with a slightly concave aspect. Anteriorly, it is in contact with the diaphysis and the proximal end of the ulnar and radial, as well as with the distal epiphysis of the ulna.

\subsubsection{Carpi (Fig. 8)}

In $M$. arrudacamposi the proximal carpus is preserved. The proximal end is articulated dorsally in the ventrolateral region of the ulnare, and the distal is articulated to digit IV. In the lateral view it is flattened.

The distal carpus is a small bone, approximately $10 \mathrm{~mm}$ in diameter. It is rounded dorsally articulating with the ventromedial portion of the distal epiphysis of the ulnare. Ventrally it is flattened and articulated to the proximal epiphyses digits of II and III.

\subsubsection{Metacarpi (Fig. 8)}

Only four of the five metacarpi present in the crocodyliform are preserved. They are approximately $25 \mathrm{~mm}$ long. The digits I, II and III are expanded and convex at the proximal ends and digit IV is more rectilinear along its length. There is a groove at the distal end,

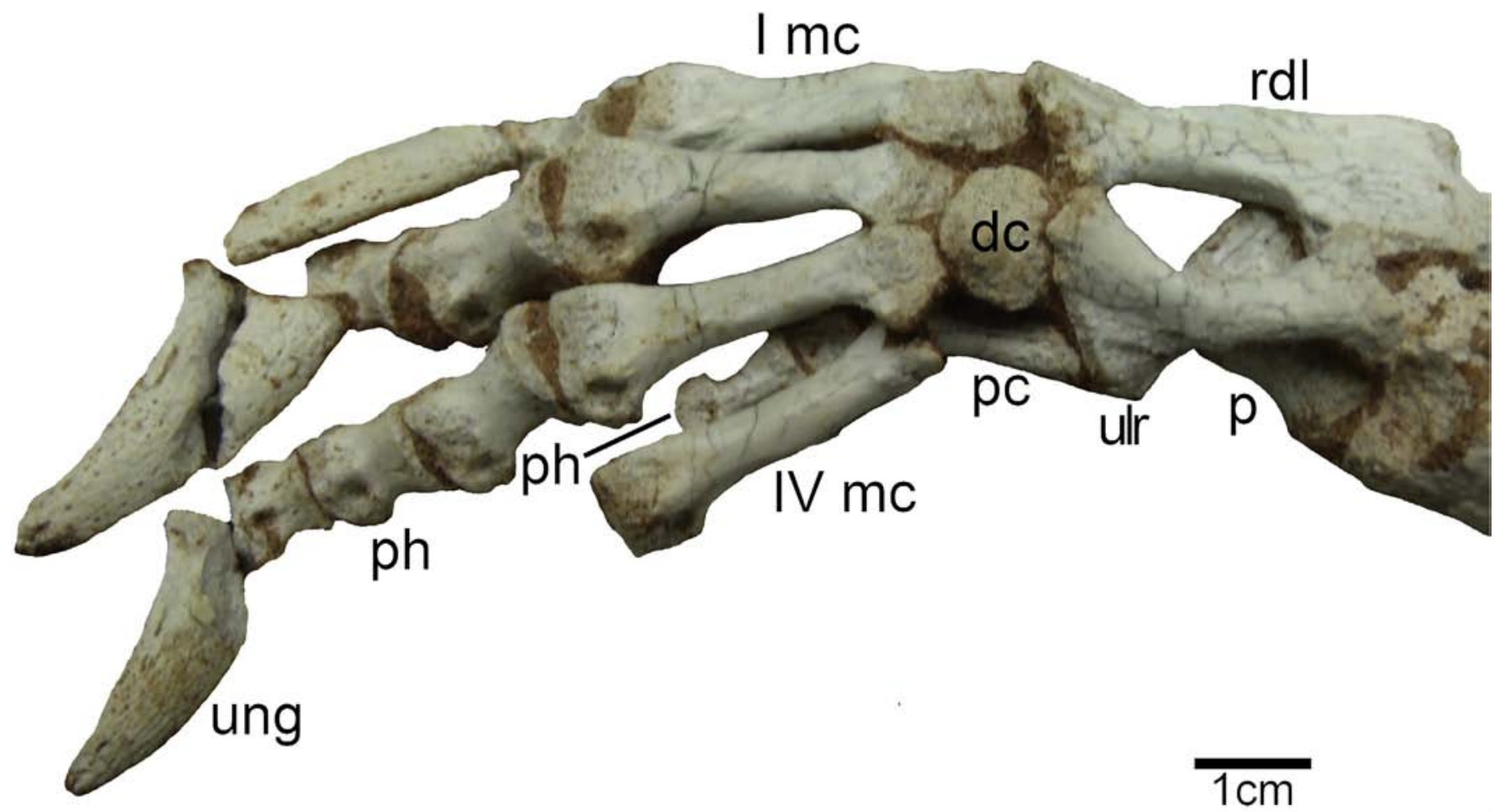

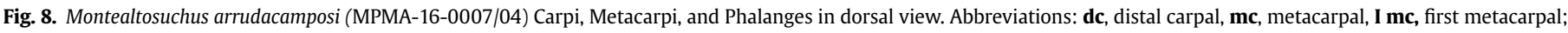
IV mc, fourth metacarpal; p, pisiform; pc, proximal carpal; ph, phalange; rdl, radiale; ulr, ulnare; ung, ungual phalanx. 
on the dorsal and lateral face of each metacarpal. On the distal surface the condyles for the articulation of the proximal phalanges are located medially and laterally.

\subsubsection{Phalanges (Figs. 8, 9)}

Only nine phalanges are preserved composing the formula $(2,3$, 4 , ?, ?). The phalanges of digits I, II and III were preserved. They have an hourglass shape (log glass) and are short. The proximal phalanges are the largest in this series of bones, at approximately $10 \mathrm{~mm}$ long, with those of digits I and II at practically the same size, becoming smaller in digit III ( $8 \mathrm{~mm})$. The medial phalanges of digit I and II, are smaller ( $5 \mathrm{~mm}$ ) than the proximal phalanges. The most distal phalanx of digit III is $3 \mathrm{~mm}$ long, but the smallest phalanx in diameter is displaced and preserved between digits III and IV. Probably it belongs to digit IV or V, which does not have any phalanx preserved in the natural position.

The proximal ends of the phalanges are concave and the distal is convex, forming the articular surfaces. Each phalanx has a rounded cavity on the left side of the distal end. Digits I, II and III preserve the ungual phalanges. These are articulated dorsally to the phalange proximal to them. The ungual phalange of digit I is larger $(20 \mathrm{~mm})$ than those of digits II and III. All have a dorsal curvature that gives them the shape of a scythe. They are laterally flattened and convex. The phalanges of digits II and III have a greater ventral concavity than that of digit I. The tips of the phalanges are sharp.

\section{Discussion}

\subsection{Morphological inferences}

The structures of the pectoral girdle and anterior appendicular skeleton of $M$. arrudacamposi have well developed ridges that probably served to fix the scapulocoracoid muscles and brachial regions ( $M$. triceps, M. scapulohumeralis, M. humeroantebrachialis inferior, $M$. triceps brachii, $M$. humeroradialis, $M$. extensor carpi radialis, $M$. flexor ulnaris, $M$. abductor radialis, $M$. supinator, $M$. pronator teres, $M$. extensor carpi radialis brevis, M. pronator quadratus, M. abductor radialis, M. extensor carpi radialis longus) (Meers, 2003). These muscles implies the possibility of an erect posture.

The bony elements of the appendicular skeleton of M. arrudacamposi are arranged vertically below the articulations of the coracoid and scapula. The humerus, ulna and radius are elongated bones, which suggests that this crocodyliform would be able to raise its body from the ground. Therefore, a hollow cylinder structure is stronger in axial compression than in bending, so that in order to have the safety factor requisite, the limb bone of a sprawling posture would be larger (in diameter) than that of an erect posture.

According to Briton (2005), this is also a described characteristic for the living crocodyliforms, which in addition to the aquatic locomotion habits, move in terrestrial environments by means of a
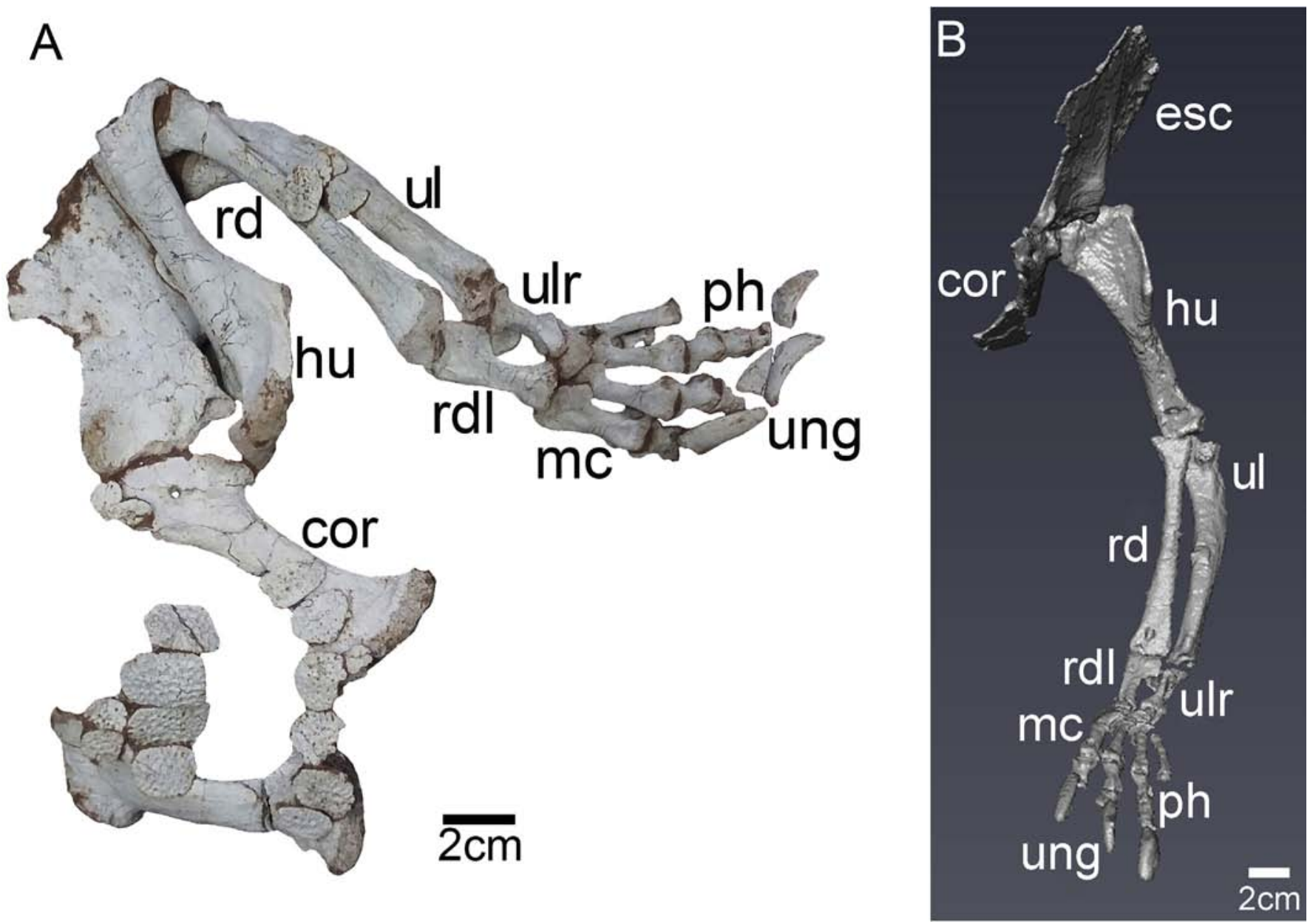

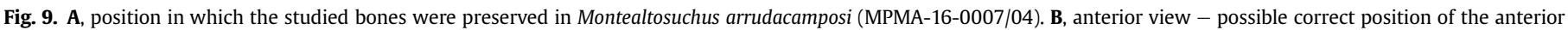
autopodium. Abbreviations: cor, coracoid; esc, scapula; hu, humerus; mc, metacarpal; ph, phalange, rd,; radius, rdl; radiale, ul; ulna, url; ulnare; ung, ungual phalanx. 
high walk, gallop (that propels the members alternately to the air) and creeping (which allows the trunk contact with the ground and members positioned laterally). Grigg and Kirshner (2015) believe that the galloping gait can be considered an almost perfect asymmetric boundary, where the anterior limbs reach the ground sequentially as the hind limbs do.

In living crocodyliforms the humerus articulates to the robust bones of the pectoral girdle (Grigg and Kirshner, 2015). The humerus of $M$. arrudacamposi also articulates to the coracoid and the scapula, however, more vertically than in living crocodyliforms which are more adapted to aquatic environments. They aid in lateral stability when a crocodile is swimming or floating. On land, limbs are able to raise and hold the heavy body uplifted from the ground.

According to Klein (2016), the distal end of the coracoid of living crocodyliforms articulates with the scapula and humerus. In Alligator the scapula is near and parallel to the spine contributing with the coracoid to the formation of the glenoid cavity. In M. arrudacamposi, the distal end of the coracoid also articulates with the scapula and humerus.

In general, the scapula of $M$. arrudacamposi is similar to that of Uberabasuchus terrificus and differs from that of Armadillosuchus arrudai, which has the same width and height (Vasconcellos, 2006; Turner, 2006). The scapular blade is expanded anteroposteriorly, differing from the patterns described for living crocodiles (Meers, 2003). It is much thinner antero-posteriorly than those of Baurusuchus albertoi, Campinasuchus dinizi and Mariliasuchus amarali (Nascimento and Zaher, 2010; Nobre and Carvalho, 2013; Cotts et al., 2017).

The posteriorly positioned concavity at the distal end in $M$. arrudacamposi, is also observed in $B$. albertoi and $C$. dinizi. In Simosuchus clarki and M. amarali this concavity is not evident (Nascimento and Zaher, 2010; Sertich and Groenke, 2010; Nobre and Carvalho, 2013; Cotts et al., 2017).

According to Leardi et al. (2015), the distal end of the scapula of Yacarerani boliviensis has an asymmetrical aspect in lateral view, with the anterior extremity more projected and proximally located than the posterior extremity. In M. amarali and S. clarki this characteristic also occurs; however, in M. arrudacamposi this extremity is not very noticeable (Sertich and Groenke, 2010; Nobre and Carvalho, 2013).

In U. terrificus, B. albertoi, C. dinizi, S. clarki, M. amarali, $Y$. boliviensis, Caipirasuchus montealtensis, as in M. arrudacamposi, the coracoids are more expanded in the distal than in the proximal portion. The coracoid foramen in these crocodyliform is circular, but in $C$. dinizi is located in the posterodorsal region and in C. montealtensis it is more compressed (Vasconcellos, 2006; Nascimento and Zaher, 2010; Iori et al., 2016; Cotts et al., 2017).

The articular surface for the scapula in Notosuchus terrestris has a triangular shape and in S. clarki and M. amarali, is curvilinear (Pol, 2005; Sertich and Groenke, 2010; Nobre and Carvalho, 2013). In Y. boliviensis this surface is 'L'-shaped (Leardi et al., 2015). This surface in M. arrudacamposi is straight as in B. albertoi (Nascimento and Zaher, 2010).

In the coracoids of $U$. terrificus and $C$. dinizi the glenoid surface was not preserved (Vasconcellos, 2006; Cotts et al., 2017). In B. albertoi, S. clarki, Y. boliviensis is posterolaterally oriented (Nascimento and Zaher, 2010; Sertich and Groenke, 2010; Leardi et al., 2015). Stratiotosuchus maxhechti shows a glenoidal process posteroventrally (Riff and Kellner, 2011). In C. montealtensis it is aligned lateroventrally (Iori et al., 2016). In M. arrudacamposi the glenoidal surface is aligned posteromedially.

The humeral articular surface is broad and convex in $S$. maxhechti, flat in $M$. amarali and slightly concave in M. arrudacamposi (Riff and Kellner, 2011; Nobre and Carvalho,
2013). The humerus of $M$. arrudacamposi articulates vertically to the coracoid, whereas in the present crocodyliform, this structure is directed to a more horizontal position.

In the lateral view the humerus of $M$. arrudacamposi exhibits a sigmoidal shape as in B. albertoi, N. terrestris, M. amarali (Pol, 2005; Nascimento and Zaher, 2010; Nobre and Carvalho, 2013). The proximal end is expanded lateromedially and an attenuated concavity occurs in anterior view. The articulation surface with the glenoid cavity (humeral head) is convex lateromedially as in B. albertoi (Nascimento and Zaher, 2010).

The deltopectoral crest develops dorsolaterally extending distally to the beginning of the diaphysis, differing from $B$. alberto $i$ and $S$. maxhechti, in which it expands anteriorly (Nascimento and Zaher, 2010; Riff and Kellner, 2011). In M. amarali and N. terrestris this crest is slightly developed and does not exhibit a marked medial deviation (Pol, 2005; Nobre and Carvalho, 2013). It is similar to that of $U$. terrificus and $A$. tsangatsangana, which in the latter extends distally by about one third of the humerus length (Vasconcellos, 2006; Turner, 2006).

In the posterior view a depression occurs in the proximal end of the humerus, however, it is not markedly circular as in S. maxhechti, N. terrestris, M. amarali, Y. boliviensis, C. montealtensis (Riff and Kellner, 2011; Nobre and Carvalho, 2013; Leardi et al., 2015; Iori et al., 2016).

The diaphysis of the humerus of M. arrudacamposi is cylindrical, approximately $40 \mathrm{~mm}$ long and $15 \mathrm{~mm}$ in diameter. The distal end is preserved in the right humerus, however, is damaged in the most peripheral part of the distal epiphysis in the left humerus. There is a pronounced concavity anteriorly. The lateral and medial epicondyles are convex, projected anteriorly and separated by a concavity. The characteristics described for the distal humerus of $M$. arrudacamposi are also present in U. terrificus, B. albertoi, N. terrestris, A. tsangatsangana, S. clarki and M. amarali (Pol, 2005; Vasconcellos, 2006; Turner, 2006; Nascimento and Zaher, 2010; Sertich and Groenke, 2010; Nobre and Carvalho, 2013). In C. dinizi the humeral diaphysis is more elongated and slightly thinner than in S. maxhechti (Riff and Kellner, 2011; Cotts et al., 2017).

In general, the ulna of $M$. arrudacamposi is similar to the ulna of B. albertoi, P. sera and C. dinizi (Nascimento and Zaher, 2010; Godoy et al., 2016; Cotts et al., 2017). The proximal end differs from that of S. clarki, and is posteriorly more inclined towards the radius (Sertich and Groenke, 2010). The diaphysis is more flattened than in B. albertoi and M. amarali (Nascimento and Zaher, 2010; Nobre and Carvalho, 2013).

The $M$. arrudacamposi radius is a straight and elongated bone as in other crocodyliforms (eg U. terrificus, B. albertoi and M. amarali) (Vasconcellos, 2006; Nascimento and Zaher, 2010; Nobre and Carvalho, 2013). In C. dinizi an anterior torsion occurs for the diaphysis portion of the radius (Cotts et al., 2017). In general, the ulna of M. arrudacamposi is similar to the ulna of B. albertoi, P. sera and C. dinizi (Nascimento and Zaher, 2010; Godoy et al., 2016; Cotts et al., 2017). The proximal end differs from that of S. clarki, and is posteriorly more inclined towards the radius (Sertich and Groenke, 2010). The diaphysis is more flattened than in B. albertoi and M. amarali (Nascimento and Zaher, 2010; Nobre and Carvalho, 2013). The $M$. arrudacamposi radius is a straight and elongated bone as in other crocodyliforms (eg U. terrificus, B. albertoi and M. amarali) (Vasconcellos, 2006; Nascimento and Zaher, 2010; Nobre and Carvalho, 2013).

According to Vasconcellos (2006), the radiale and ulnare of $U$. terrificus are expanded at the distal and proximal ends and have diaphyeses (or shafts) which are relatively long, narrow and subcircular in cross-section. M. arrudacamposi also presents these characteristics for the radiale and the ulnare. 
As in M. arrudacamposi, the B. albertoi ulnare is smaller than the radial, the distal end is more expanded than the proximal one and has a triangular shape due to a narrow anterior extension. This form is also present in U. terrificus (Vasconcellos, 2006; Nascimento and Zaher, 2010). In C. dinizi the radiale and ulnare are longer than they are wide, but the radiale is more robust and higher than the ulnare, as in M. arrudacamposi (Cotts et al., 2017).

Vasconcellos (2006) described for U. terrificus and Nascimento and Zaher (2010) for B. albertoi only the distal carpus, which is also preserved in $M$. arrudacamposi. In $C$. dinizi the distal carpus is articulated to the ulnare in a ventral region to the articular facet of the distal end of the bone (Cotts et al., 2017). In M. arrudacamposi the articular surface with the ulnare is rounded and the contact surface with the metacarpals is concave. In U. terrificus, it is in direct contact with III and IV (Vasconcellos, 2006). In B. albertoi, the contact of the distal carpus is with III, IV and V metacarpi (Nascimento and Zaher, 2010). In M. arrudacamposi it is only in contact with digits II and III.

Only four (I, II, II, IV) out of the five metacarpi present in crocodilians are preserved (Romer, 1956). They are moderately short compared to those of B. albertoi (Nascimento and Zaher, 2010). They are more similar to those of $U$. terrificus, which are moderately elongated and robust (Vasconcellos, 2006). In all the peirosaurids, $M$. arrudacamposi, $U$. terrificus and B. albertoi, the greatest expansion in the proximal portion occurs in digit I. All have a distal expansion that allows the proximal phalanges to articulate.

In M. arrudacamposi a displaced phalanx is preserved, which is between the digits III and IV, and nine articulated phalanges distributed as follows: digits I-2, II-3, III-4, IV- ?, V- ?. This formula differs from $U$. terrificus (3-4-5-3-?) And that of $C$. dinizi (2-3-4-5-3) but is identical for digits I, II and III of $B$. Albertoi (2-3-4-4-3) (Vasconcellos, 2006; Nascimento and Zaher, 2010; Cotts et al., 2017). In M. arrudacamposi the proximal phalanges of metacarpals I and II are the most robust. This condition also occurs in U. terrificus (Vasconcellos, 2006). As in B. albertoi, there is a decrease in the length of the proximal phalanx compared to the distal phalanges. The ungual phalanges are present in the digits I, II and III of $M$. arrudacamposi as well as in $U$. terrificus and $B$. albertoi (Vasconcellos, 2006; Nascimento and Zaher, 2010).

According to Vasconcellos (2006), the claws of Baurusuchidae are robust and almost twice as curved as the $U$. terrificus claws which are thin and have laminated ventral edges. The ungual phalanges of $M$. arrudacamposi are similar to those of $U$. terrificus, but they do not appear to articulate laterally with each other, as suggested by Vasconcellos (2006).

\subsection{Morphofunctional inferences}

In order to understand the locomotion of an animal in the morphofunctional analysis of the post-cranial structures of paleovertebrates, the supporting articular surfaces need to be evaluated. This evaluation is essential because their conformation is the way they are constructed thus, becoming an important aspect for understanding the articulation of limb bones. New methodologies, such as 3D reconstructions in life position of adjacent articulated fossilized bones, contribute in the morphofunctional studies of paleovertebrates.

Authors such as Duarte et al. (2011) used a virtual threedimensional model of $B$. salgadoensis, obtained through a CT scan to virtually manipulate the appendicular bone elements of this crocodyliform, which by the way were fully articulated. After separation, it was possible to virtually allocate them to a position as close as possible to the original in life.

Like B. salgadoensis, the appendicular bony elements of M. arrudacamposi were also separated and virtually aligned in a more plausible life-like position. The 3D realignment of the bones, the pectoral girdle and anterior appendicular skeleton of M. arrudacamposi, showed that this crocodyliform had a more vertical position than of its anterior limbs.

The pectoral girdle of living crocodyliforms does not connect the axial skeleton and is held in place by the muscles and fascias (Grigg and Kirshner, 2015). The scapula is larger than the coracoid; the latter articulates in the ventral region of the scapula and along with the glenoid process, forms the glenoidal cavity, that is an articular surface for the head of the humerus (Vieira et al., 2016). The scapula in living crocodyliforms is arched over the coracoid (Grigg and Kirshner, 2015). Also, in M. arrudacamposi, the bones of the pectoral girdle do not articulate to the axial skeleton.

The scapula and the coracoids have been preserved almost in their original position. The coracoids are connected by a set of osteoderms and the scapula of $M$. arrudacamposi is not arched as in living crocodyliforms, suggesting a more vertical articulation of the humerus to the elements of the pectoral girdle (Fig. 5A-D).

Clark et al. (2004) believed that the alignment of the glenoid fossa, the convex head on the humerus, the lack of rotation around the distal end of the ulna, the compact metacarpals, and the reduced outer digits, they all indicate that limb moved in a verticalparasagittal plane. This position is classified by von Huene (1913) as adducted, in which the animal's body assumes a more upright position (Blob, 2001; Berman and Henrici, 2003).

In this study we observed that the characteristics described by Clark et al. (2004) are also present in the structure of M. arrudacamposi. In this crocodyliform the glenoidal surface is posteromedially aligned, and the head of the humerus, which articulates with the glenoid cavity, is convex.

The left humerus of $M$. arrudacamposi was preserved invertedly from its position in life, suggesting there was a rotation of this bone around the articular surface of the coracoid during the process of preservation. This structure was virtually disarticulated and repositioned in the most suitable living position. The virtual articular adjustment between the coracoid, scapula and the positioning of the humerus next to the coracoid, also allowed the repositioning of the radius, ulna and elements of the front autopodium.

For Clark et al. (2004), the conformation of the shoulder and wrist joints and the reduction in the size of the external digits may be evidence that the anterior limbs are positioned directly under the body. These authors have analyzed the pectoral girdle fossils and the anterior limb bones of Junggarsuchus sloan. They concluded its humerus is different from any other Crocodyliformes because it has a well-developed hemispherical head projecting perpendicular to the long axis of the diaphysis, with a convex proximal articulation surface.

The long elements of the anterior appendages of Uberabasuchus terrificus are generally rectilinear and robust with well developed articular surfaces and condyles, similar to those of M. arrudacamposi. According to Vasconcellos (2006) the Peirosauridae could have had a more parasagittal posture on land than that of recent Crocodyliformes.

Vasconcellos et al. (2007) analyzed the appendicular bones of B. salgadoensis and concluded they are long and robust structures. The anterior appendicular bones are almost straight and have broad articular facets. These aspects suggest a more upright posture for this crocodyliform. M. arrudacamposi has elongated appendicular bones as well; however, the articular facet contact between the coracoid and humerus is respectively concave and convex.

Another baurusuchid that has elements of the anterior limbs preserved is the Stratiotosuchus maxhechti. Riff and Kellner (2011) affirm the humerus of $S$. maxhechti has a broad and convex head which articulates to the glenoid process posteroventrally, thus enabling movement of the anterior limbs in the parasagittal plane. The aspects of the glenoid cavity and humeral head of S. maxhechti are similar to those of $M$. arrudacamposi. 

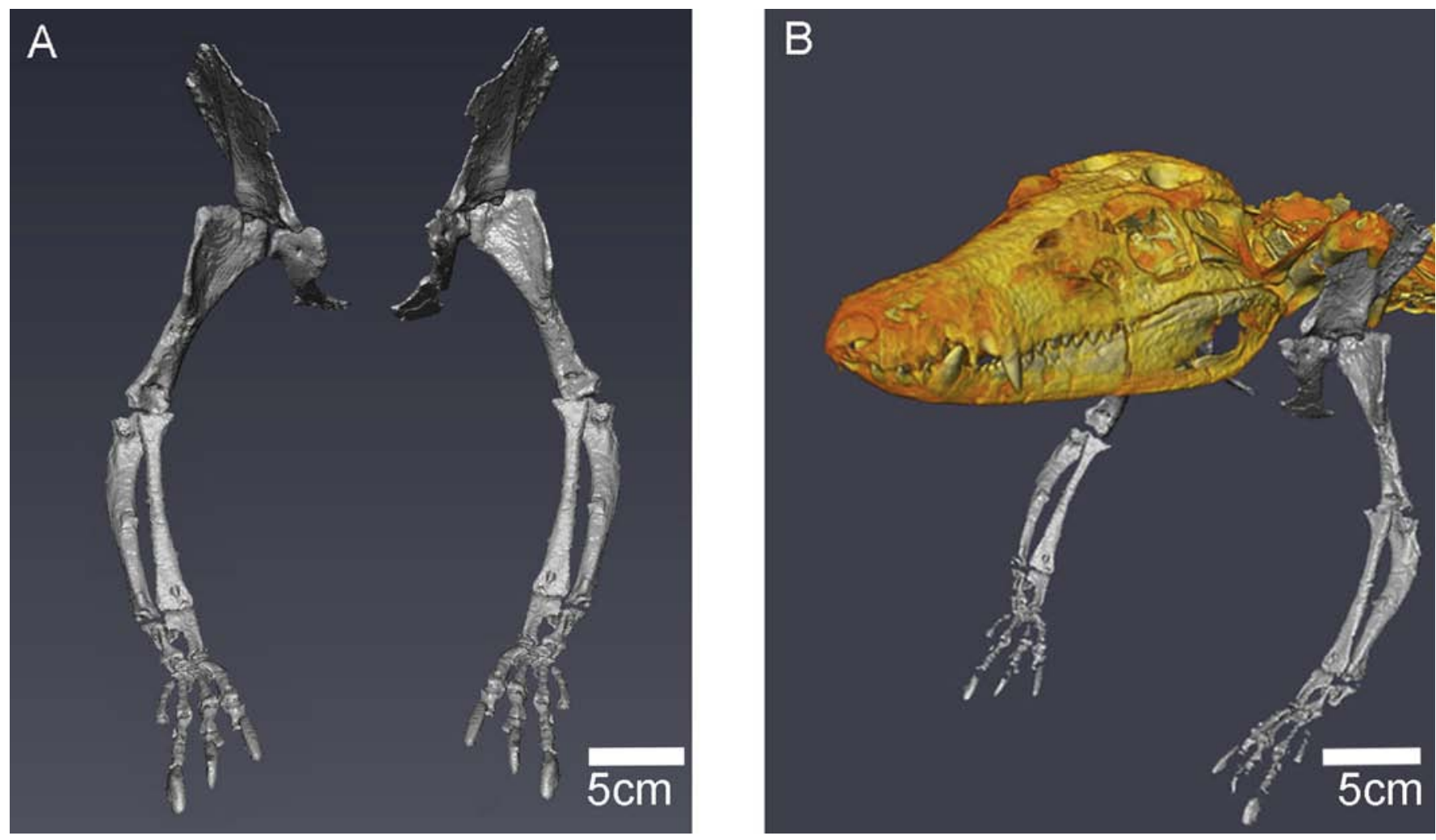

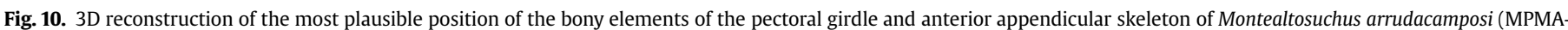
16-0007/04). A, The frontal view (scapula, radius, ulna and front autopodium on the right side are mirror images, as these bones were not preserved.) B, left lateral view.

The characteristics of the structures preserved in the bony elements of the pectoral girdle and anterior appendages of Mariliasuchus amarali differ from those observed in M. arrudacamposi. The articular facet of the scapula with the coracoid of $M$. amarali is located along the anterior half of the distal end. In the coracoid, the articular surface for the humeral head is flat, whereas in M. arrudacamposi is convex. Nobre and Carvalho (2013) concluded that $M$. amarali did not have an upright posture, or semi-erect as proposed for $M$. arrudacamposi, but rather a sprawling posture, similar to the present crocodyliforms.

In addition to the orientation of the glenoid surface, the convex head of the humerus led Clark et al. (2004) to suggest that the lack of rotation around the distal end of the ulna, compact metacarpals, and reduced exterior digits was a sign that the anterior limb could have moved vertically in the parasagittal plane.

In $M$. arrudacamposi the distal extremity of the ulna and the radius were not preserved, so it is not possible to infer the form of rotation around this extremity. However, the metacarpals are short and close to each other, a condition similar to those of S. maxhechti, which are compressed together and not spread laterally as in living crocodyliform. These aspects suggest a digitigrade posture of the manus, where only the distal portions of the digits rest on the ground (Clark et al., 2004; Riff and Kellner, 2011) (Fig. 10). Both $M$. arrudacamposi and $U$. terrificus have short robust metacarpals. According to Vasconcellos (2006) these characteristics indicate the metacarpals could have been adapted to support the inherent loads from terrestrial locomotion.

\section{Conclusion}

The exceptional preservation of the bony elements of the pectoral girdle and the anterior appendicular skeleton of the
M. arrudacamposi holotype, the virtual disarticulation with a subsequent 3D reorganization of these structures, articulating them in the position closest to the original, suggest this Peirosauridae species inhabited terrestrial environments and moved around by means of a high walk.

The right and left coracoids joined by the pectoral osteoderms indicate these structures were preserved essentially in their original position. In conjunction with these features, the articulation surfaces, mainly of the scapula, coracoid and humerus, showed that the anterior limbs of $M$. arrudacamposi had a more upright position compared to the living crocodyliforms. The anatomical arrangement of long bones and autopodal elements, such as the elongated metacarpals close to each other, indicate that $M$. arrudacamposi had cursorial habits, allowing them to wander in terrestrial environments in search of prey.

\section{Acknowledgements}

We thank to the crew of Museu de Paleontologia "Prof. Antonio Celso Arruda Campos", Antonio Celso de Arruda Campos (in memoriam), Cledinei A. Francisco, Fabiano Vidoi Iori, Deverson da Silva (Pepi), Paulo Gilberto da Rocha Tavares, José Augusto Bugarelli, Angélica Fernandes, Fernando Henrique Morais da Rocha and Hellen Tavares, for the help in the field and laboratory work. The paleoartist Pepi for the permission to use the reconstruction image of Montealtosuchus. The geologist Fábio Branco, Prof. Paulo Hilário Nascimento Saldiva and Prof. Edson Amaro Jr. supported the tomography analysis in Institute of Radiology, Faculty of Medicine, São Paulo USP, Brazil. Jorge Vicente Lopes da Silva and crew to the analysis in the Three-Dimensional Technologies Division, Renato Archer Information Technology Center, Campinas, São Paulo, Brazil. Special thanks are due to the Editor-in-Chief, Eduardo A. 
Koutsoukos and two anonymous reviewers contribution, by the depth of their comments, in their respective attempts to help to improve the paper. This study was supported by Coordenação de Aperfeiçoamento de Pessoal de Nível Superior (CAPES), Conselho Nacional de Desenvolvimento Científico e Tecnológico (CNPq) and Fundação Carlos Chagas Filho de Amparo a Pesquisa do Estado do Rio de Janeiro (FAPERJ).

\section{References}

Andrade, M.B., Bertini, R.J., 2008. A new Sphagesaurus (Mesoeucrocodylia: Notosuchia) from the Upper Cretaceous of Monte Alto City (Bauru Basin, Brazil), and a revision of the Sphagesauridae. Historical Biology 20, 101-136.

Bakker, R.T., 1971. Dinosaur physiology and the origin of mammals. Evolution 25, 636-658.

Basilici, G., Dal, B., Führ, P.F., Ladeira, F.S.B., 2009. Climate-induced sedimentpalaeosol cycles in a Late Cretaceous dry aeolian sand sheet: Marília Formation (North-West Bauru Basin, Brazil). Sedimentology 56 (6), 1876-1904.

Benton, M.J., 2010. Studying function and behavior in the fossil record. PLoS Biology 8 (3), e1000321.

Berman, D.S., Henrici, A.C., 2003. Homology of the astragalus and structure and function of the tarsus of Diadectidae. Journal of Paleontology 77 (01), 172-188.

Blob, R.W., 2001. Evolution of hindlimb posture in nonmammalian therapsids: biomechanical tests of paleontological hypotheses. Paleobiology 27 (1), 14-38

Bonaparte, J.F., 1986. The dinosaurs (Carnosaurs, Allosaurids, Sauropods, Cetiosaurids) of the Middle Jurassic of Cerro Cóndor (Chubut, Argentina). Annales de Paléontologie Vert.-Invert 72 (4), 325-386.

Briton, A.R.C., 2005. Crocodilian Natural History and Conservation. Online version at: http://www.crocodilian.com.

Buckley, G.A., Brochu, C.A., 1999. An enigmatic new crocodile from the Upper Cretaceous of Madagascar. Special Papers in Palaeontology 60, 149-175.

Buckley, G.A., Brochu, C.A., Krause, D.W., Pol, D., 2000. A pugnosed crocodyliform from the Late Cretaceous of Madagascar. Nature 405, 941-944.

Campos, D.A., Suarez, J.M., Riff, D., Kellner, A.W.A., 2001. Short note on a new Baurusuchidae (Crocodyliformes, Metasuchia) from the Upper Cretaceous of Brazil. Boletim do Museu Nacional, Nova Série, Geologia 57,1-7.

Carvalho, I.S., Bertini, R.J., 1999. Mariliasuchus: um novo Crocodylomorpha (Notosuchia) do Cretáceo da Bacia Bauru, Brasil. Geología Colombiana-An International Journal on Geosciences 24, 83-105.

Carvalho, I.S., Bertini, R.J., 2000. Contexto geológico dos notossúquios (Crocodylomorpha) cretácicos do Brasil. Geologia Colombiana, Santafé de Bogotá 25, 163-184.

Carvalho, I.S., Ribeiro, L.C.B., Avilla, L.S., 2004. Uberabasuchus terrificus sp. nov. a new Crocodylomorpha from the Bauru Basin (Upper Cretaceous), Brazil. Gondwana Research 7 (4), 975-1002.

Carvalho, I.S., Campos, A.C.A., Nobre, P.H., 2005. Baurusuchus salgadoensis, a new crocodylomorpha from the Bauru Basin (Cretaceous), Brazil. Gondwana Research 8 (1), 11-30.

Carvalho, I.S., Vasconcellos, F.M., Tavares, S.A.S., 2007. Montealtosuchus arrudacamposi, a new peirosaurid crocodile (Mesoeucrocodylia) from the Late Cretaceous Adamantina Formation of Brazil. Zootaxa 1607, 35-46.

Carvalho, I.S., Gasparini, Z.B., Salgado, L., Vasconcellos, F.M., Silva Marinho, T., 2010. Climate's role in the distribution of the Cretaceous terrestrial Crocodyliformes throughout Gondwana. Palaeogeography, Palaeoclimatology, Palaeoecology 297 (2), 252-262.

Carvalho, I.S., Teixeira, V.P.A., Ferraz, M.L.F., Ribeiro, L.C.B., Martinelli, A.G., Neto, F.M., Ferraz, P.F., 2011. Campinasuchus dinizi gen. et sp. nov., a new Late Cretaceous baurusuchid (Crocodyliformes) from the Bauru Basin, Brazil. Zootaxa 2871 (2011), 19-42.

Charig, A.J., 1972. The evolution of the archosaur pelvis and hindlimb: an explanation in functional terms. In: Joysey, K.A., Kemp, T.S. (Eds.), Studies in Vertebrate Evolution. Oliver and Boyd, Edinburgh, pp. 121-155.

Clark, J.M., Xu, X., Forster, C.A., Wang, Y., 2004. A Middle Jurassic 'sphenosuchian' from China and the origin of the crocodylian skull. Nature 430 (7003), 1021-1024.

Cotts, L., Pinheiro, A.E.P., da Silva Marinho, T., de Souza Carvalho, I., Di Dario, F., 2017. Postcranial skeleton of Campinasuchus dinizi (Crocodyliformes, Baurusuchidae) from the Upper Cretaceous of Brazil, with comments on the ontogeny and ecomorphology of the species. Cretaceous Research 70, 163-188.

Daudin, F.M., 1802. Histoire Naturelle Générale et Particulière des Reptiles, 2. Dufart.

Dias-Brito, D., Musacchio, E.A., De Castro, J.C., Maranhão, M.S.A.S., Suárez, J.M. Rodrigues, R., 2001. Grupo Bauru: uma unidade continental do Cretáceo no Brasil-concepções baseadas em dados micropaleontológicos, isotópicos e estratigráficos. Revue de Paléobiologie 20 (1), 245-304.

Duarte, K.O., Vasconcellos, F.M., Marinho, T.S., Carvalho, I.S., 2011. Modelagem virtual 3D: modelo 3D virtual de Baurusuchus salgadoensis (Crocodyliformes: Baurusuchidae) com base em imageamento tomográfico. In: Carvalho, Ismar de Souza, Srivastava, Narendra Kumar, Strohschoen Jr., Oscar, Lana, Cecília Cunha (Eds.), Paleontologia: Cenários de Vida, 4. Editora Interciência, Rio de Janeiro, pp. 523-533.
Fernandes, L.A., 1998. Estratigrafia e evolução geológica da parte oriental da Bacia Bauru (Ks, Brasil). Universidade de São Paulo (D.Sc thesis).

Fernandes, L.A., Coimbra, A.M., 1996. A Bacia Bauru (Cretáceo Superior, Brasil). Anais da Academia Brasileira de Ciências 68 (2), 195-205.

Fernandes, L.A., Coimbra, A.M., 2000. Revisão estratigráfica da parte oriental da Bacia Bauru (Neocretáceo). Revista Brasileira de Geociências 30 (4), 723-734.

Godoy, P.L., Bronzati, M., Eltink, E., Júlio, C.D.A., Cidade, G.M., Langer, M.C., Montefeltro, F.C., 2016. Postcranial anatomy of Pissarrachampsa sera (Crocodyliformes, Baurusuchidae) from the Late Cretaceous of Brazil: insights on lifestyle and phylogenetic significance. Peerj 4, e2075.

Grigg, G., Kirshner, D., 2015. Biology and evolution of crocodylians. CSIRO Publishing, p. 650.

Hoffstetter, R., Gasc, J.P., 1973. Vertebrae and ribs of modern reptiles. In: Gans, Carl, Bellairs, A.d'A., Parsons, Thomas (Eds.), Biology of Reptilia, vol. 1. London Academic Press, London, pp. 201-233.

Iori, F.V., Carvalho, I.S., Silva Marinho, T., 2016. Postcranial skeletons of Caipirasuchus (Crocodyliformes, Notosuchia, Sphagesauridae) from the Upper Cretaceous (Turonian-Santonian) of the Bauru Basin, Brazil. Cretaceous Research 60, 109-120.

Klein, G.F., 2016. Skeletal Anatomy of Alligator and Comparison with Thecachampsa. Calvert Marine Museum, p. 70.

Kischlat, E.E., 2000. Tecodôncios: a aurora dos arcossáurios no Triássico. Paleontologia do Rio Grande do Sul. CIGO/UFRGS, Porto Alegre, pp. 273-316.

Leardi, J.M., Pol, D., Novas, F.E., Suárez Riglos, M., 2015. The postcranial anatomy of Yacarerani boliviensis and the phylogenetic significance of the notosuchian postcranial skeleton. Journal of Vertebrate Paleontology 35 (6), e995187.

Marinho, T.S., Carvalho, I.S., 2009. An armadillo-like sphagesaurid crocodyliform from the Late Cretaceous of Brazil. Journal of South American Earth Sciences 27 (1), 36-41.

Meers, M.B., 2003. Crocodylian forelimb musculature and its relevance to Archosauria. The Anatomical Record Part A: Discoveries in Molecular, Cellular, and Evolutionary Biology 274 (2), 891-916.

Menegazzo, M.C., Catuneanu, O., Chang, H.K., 2016. The South American retroarc foreland system: the development of the Bauru Basin in the back-bulge province. Marine and Petroleum Geology 73, 131-156.

Montefeltro, F.C., Larsson, H.C., Langer, M.C., 2011. A new baurusuchid (Crocodyliformes, Mesoeucrocodylia) from the Late Cretaceous of Brazil and the phylogeny of Baurusuchidae. PLoS One 6 (7), e21916.

Mook, C.C., 1921. Notes on the postcarnial skeleton of Crocodylia. Bulletin of American Museum of Natural History 44, 67-100.

Nascimento, P.M. Zaher, H., 2010. A new species of Baurusuchus (Crocodyliformes, Mesoeucrocodylia) from the Upper Cretaceous of Brazil, with the first complete postcranial skeleton described for the family Baurusuchidae. Papéis Avulsos de Zoologia 50 (21), 323-361.

Nobre, P.H., Carvalho, I.D.S., 2013. Postcranial skeleton of Mariliasuchus amarali Carvalho and Bertini, 1999 (Mesoeucrocodylia) from the Bauru Basin, Upper Cretaceous of Brazil. Ameghiniana 50 (1), 98-113.

Novas, F.E., Pais, D.F., Pol, D., Carvalho, I.D.S., Scanferla, A., Mones, A., Riglos, M.S., 2009. Bizarre notosuchian crocodyliform with associated eggs from the Upper Cretaceous of Bolivia. Journal of Vertebrate Paleontology 29 (4), 1316-1320.

Pol, D., 2005. Postcranial remains of Notosuchus terrestris Woodward (Archosauria: Crocodyliformes) from the Upper Cretaceous of Patagonia, Argentina. Ameghiniana 42 (1), 21-38.

Richardson, K.C., Webb, G.J.W., Manolis, S.C., 2002. Crocodiles: Inside out. A guide to the crocodilians and their functional morphology. Surrey Beatty and Sons, p. 172.

Riff, D., Kellner, A.W.A., 2011. Baurusuchid crocodyliforms as theropod mimics: clues from the skull and appendicular morphology of Stratiotosuchus maxhechti (Upper Cretaceous of Brazil). Zoological Journal of the Linnean Society 163 (s1), S37-S56.

Romer, A.S., 1956. The osteology of the reptiles. Univ. Chicago Press, p. 772.

Selden, P.A., 1990. Biomechanics. In: Briggs, D.E.G., Crowther, P.R. (Eds.), Paleobiology: A synthesis. Blackwell Science, pp. 318-322.

Sennikov, A.G., 1987. Basic evolutionary laws of development of locomotor apparatus in archosaurs. Paleontological Journal 4, 63-72.

Sertich, J.J., Groenke, J.R., 2010. Appendicular skeleton of Simosuchus clarki (Crocodyliformes: Notosuchia) from the Late Cretaceous of Madagascar. Journal of Vertebrate Paleontology 30 (Suppl. 1), 122-153.

Tarsitano, S, 1982. The crocodilian tarsus and the evolution of the Archosauria. Neues Jahrbuch fur Geologie und Palaontologie 164, 199-202.

Tavares, S.A.S., Ricardi-Branco, F., Carvalho, I.S., 2015. Osteoderms of Montealtosuchus arrudacamposi (Crocodyliformes, Peirosauridae) from the Turonian-Santonian (Upper Cretaceous) of Bauru Basin, Brazil. Cretaceous Research 56, 651-661.

Turner, A.H., 2006. Osteology and phylogeny of a new species of Araripesuchus (Crocodyliformes: Mesoeucrocodylia) from the Late Cretaceous of Madagascar. Historical Biology 18 (3), 255-369.

Vasconcellos, F.M., 2006. Descrição do pós-crânio de Uberabasuchus terrificus Carvalho, Ribeiro \& Avilla, 2004 (Crocodyliformes, Peirosauridae) do Cretáceo Superior da Bacia Bauru: Inferências morfofuncionais e paleoautoecológicas. Universidade Federal do Rio de Janeiro, p. 174 (MSc. thesis).

Vasconcellos, F.M., Marinho, T.S., Carvalho, I.S., 2007. The locomotion pattern of Baurusuchus salgadoensis Carvalho, Nobre, and Campos, 2005 and the 
distribution of Baurusuchidae in Gondwanaland. Nature Precedings. http:// dx.doi.org/10.1038/npre.2007.808.1.

Vieira, L.G., Santos, A.L., Lima, F.C., Mendonça, S.H., Menezes, L.T., Sebben, A., 2016 Osteologia de Melanosuchus niger (Crocodylia: Alligatoridae) e a evidência evolutiva. Pesquisa Veterinária Brasileira 36 (10), 1025-1044.
Von Huene, F., 1913. Beobachtungen über die Bewegungsart der Extremitäten bei Krokodilien. Biologisches Zentralblatt 33, 468-472.

Woodward, A.S., 1896. On two mesozoic crocodilians, Notosuchus (genus novum) and Cynodontosuchus (gen. nov.) from the red sandstones of Territory of Neuquén (Argentina). Anales del Museo de La Plata 4, 1-20. 